\title{
Being impulsive and obese increases susceptibility to speeded detection of high-calorie foods
}

Citation for published version (APA):

Bongers, P., van de Giessen, E., Roefs, A., Nederkoorn, C., Booij, J., van den Brink, W., \& Jansen, A. (2015). Being impulsive and obese increases susceptibility to speeded detection of high-calorie foods. Health Psychology, 34(6), 677-685. https://doi.org/10.1037/hea0000167

Document status and date:

Published: 01/06/2015

DOI:

10.1037/hea0000167

Document Version:

Publisher's PDF, also known as Version of record

Document license:

Taverne

Please check the document version of this publication:

- A submitted manuscript is the version of the article upon submission and before peer-review. There can be important differences between the submitted version and the official published version of record.

People interested in the research are advised to contact the author for the final version of the publication, or visit the DOI to the publisher's website.

- The final author version and the galley proof are versions of the publication after peer review.

- The final published version features the final layout of the paper including the volume, issue and page numbers.

Link to publication

\footnotetext{
General rights rights.

- You may freely distribute the URL identifying the publication in the public portal. please follow below link for the End User Agreement:

www.umlib.nl/taverne-license

Take down policy

If you believe that this document breaches copyright please contact us at:

repository@maastrichtuniversity.nl

providing details and we will investigate your claim.
}

Copyright and moral rights for the publications made accessible in the public portal are retained by the authors and/or other copyright owners and it is a condition of accessing publications that users recognise and abide by the legal requirements associated with these

- Users may download and print one copy of any publication from the public portal for the purpose of private study or research.

- You may not further distribute the material or use it for any profit-making activity or commercial gain

If the publication is distributed under the terms of Article $25 \mathrm{fa}$ of the Dutch Copyright Act, indicated by the "Taverne" license above, 


\title{
Being Impulsive and Obese Increases Susceptibility to Speeded Detection of High-Calorie Foods
}

\author{
Peggy Bongers \\ Maastricht University
}

\author{
Anne Roefs and Chantal Nederkoorn \\ Maastricht University
}

\author{
Elsmarieke van de Giessen \\ University of Amsterdam
}

\author{
Jan Booij and Wim van den Brink \\ University of Amsterdam
}

\begin{abstract}
Anita Jansen
Maastricht University

Objective: Overeating and obesity are associated with impulsivity. In studies among patients with a substance use disorder, impulsivity was found to be associated with substance-related attentional bias. This study examined whether obesity, impulsivity and food craving are associated with an attentional bias for high-calorie food. Methods: Obese $(n=185$, mean BMI $=38.18 \pm 6.17)$ and matched healthyweight $(n=134$, mean BMI $=22.35 \pm 1.63)$ men $(27.9 \%)$ and women $(72.1 \%)$, aged $18-45$ years, took part in the study. Participants were tested on several self-report and behavioral measures of impulsivity (i.e., response inhibition and reward sensitivity) and self-reported trait craving. In addition, they performed a visual search task to measure attentional bias for high- and low-caloric foods. Results: Self-reported impulsivity influenced the relationship between weight status and detection speed of highand low-caloric food items: High-impulsive participants with obesity were significantly faster than high-impulsive healthy-weight participants in detecting a high-caloric food item among neutral items, whereas no such difference was observed among low-impulsive participants. No significant effects were found on low-caloric food items, for trait craving or any of the behavioral measures of impulsivity. Conclusion: Self-reported impulsivity, but not trait craving or behavioral measures of impulsivity, is associated with an attentional bias for high-caloric foods, but only in people with obesity. It is in particular the speedy detection of high-caloric foods in the environment that characterizes the impulsive person with obesity, which in turn may cause risky eating patterns in a society were high-caloric food is overly present.
\end{abstract}

Keywords: attention bias, impulsivity, food craving, obesity, toxic environment

Attentional bias for high-calorie food is putatively related to increased food cravings and a risk of overeating (Kemps \& Tiggemann, 2009; Smeets, Roefs, \& Jansen, 2009; Werthmann, Field, Roefs, Nederkoorn, \& Jansen, 2014; Werthmann et al., 2011). As such, this type of attentional bias can be viewed as an early cognitive part of a chain of subjective and behavioral cue reactivity responses (desire, craving, salivation, approaching) during food cue exposure. Cue reactivity, including attentional biases, to addiction-related cues has been associated with substance use and relapse risk (Field \& Cox,
2008), and recent studies have shown that the personality trait of impulsivity is positively related to increased cue reactivity: More impulsive heavy drinkers show increased cue reactivity (craving) during cue exposure compared with less impulsive heavy drinkers (Papachristou, Nederkoorn, Havermans, van der Horst, \& Jansen, 2012). Impulsivity is also purportedly positively related to attention biases for substance-related cues (Coskunpinar \& Cyders, 2013; Field \& Cox, 2008). Like substance use disorders, obesity and overeating are characterized by increased impulsivity. Higher levels of impul-
This article was published Online First November 3, 2014.

Peggy Bongers, Department of Clinical Psychological Science, Maastricht University; Elsmarieke van de Giessen, Department of Nuclear Medicine, Academic Medical Center, University of Amsterdam; Anne Roefs and Chantal Nederkoorn, Department of Clinical Psychological Science, Maastricht University; Jan Booij, Department of Nuclear Medicine, Academic Medical Center, University of Amsterdam; Wim van den Brink, Department of Psychiatry, Academic Medical Center, University of Amsterdam; Anita Jansen, Department of Clinical Psychological Science, Maastricht University.

Elsmarieke van de Giessen is now at Department of Psychiatry, Columbia University College of Physicians and Surgeons.
This study was partly made possible by financial support of the Netherlands Organisation for Scientific Research (NWO), Vici Grant 453.10.006, awarded to Anita Jansen. We thank Nicolette Siep, Bart van den Boogard, Mieke Dorssers, Melanie de Wit, Brit Giesbertz, Linda Hermens, and Michelle de Haan for their assistance in conducting the study. The authors would also like to thank Co-Eur, Center for Obesity and Eating Disorders, for their help in the recruitment and testing of participants.

Correspondence concerning this article should be addressed to Peggy Bongers, Faculty of Psychology and Neuroscience, Maastricht University, CPS, Department of Eating Disorders and Addiction, P.O. Box 616, 6200 MD Maastricht, The Netherlands. E-mail: peggy.bongers@maastrichtuniversity.nl 
sivity are associated with (Galanti, Gluck, \& Geliebter, 2007; Guerrieri, Nederkoorn, \& Jansen, 2007a)—and have even been found to lead to (Guerrieri, Nederkoorn, Schrooten, Martijn, \& Jansen, 2009; Guerrieri et al., 2007b; Jansen et al., 2009)—increased food intake.

Impulsivity is a multidimensional construct (Dawe \& Loxton, 2004; de Wit, 2009; Whiteside \& Lynam, 2001), which can be conceptualized in different ways. One such conceptualization is a division into three broad components: self-reported trait impulsivity, impaired response-inhibition/impulsive-action, and increased delay-discounting/impulsive-choice (Guerrieri, Nederkoorn, \& Jansen, 2008). All three impulsivity components have been linked to overeating and obesity (Guerrieri et al., 2008; Mobbs, Crépin, Thiéry, Golay, \& Van der Linden, 2010; Nederkoorn, Smulders, Havermans, Roefs, \& Jansen, 2006; Rydén et al., 2003). This influence of impulsivity on overeating might moderate an attentional bias for food. As impulsive people are characterized by, among others, increased distraction, acting without thinking, an inability to inhibit inappropriate responses, and a hypersensitivity to immediate reward (Reynolds, Ortengren, Richards, \& de Wit, 2006), this could lead their attention to be more easily and more automatically drawn to salient and rewarding stimuli, such as high-calorie foods. In addition, they might also experience more difficulties in directing their attention away from such stimuli. Although several (Castellanos et al., 2009; Nijs, Muris, Euser, \& Franken, 2010; Werthmann et al., 2011), but not all (Nummenmaa, Hietanen, Calvo, \& Hyönä, 2011), studies have shown that attentional bias for high-calorie food cues is more frequent in people with overweight and obesity than in healthy-weight participants, only one study investigated the relationship between impulsivity and food attentional bias (Hou et al., 2011). The authors found a positive correlation between self-reported trait impulsivity and attentional bias, as measured by a dot probe task. Other studies (Kemps \& Tiggemann, 2009; Smeets et al., 2009; Werthmann et al., 2011) found attentional biases for food to be positively influenced by state craving, but no data are currently available on the association between attentional bias and a general trait craving for high-calorie foods. Because different kinds of food constantly and simultaneously surround us, a general food craving in combination with an attentional bias would make the current environment even more tempting and more difficult to resist.

Taken together, studies have clearly shown an association between impulsivity and increased food intake and overweight. In addition, in the field of substance use disorders, higher levels of impulsivity are associated with biases in attention for substance cues. However, it is unknown whether impulsivity is also related to an attentional bias for tasty high-calorie food cues, and if so, how weight status affects this relationship. In the present study, it is hypothesized that higher levels of impulsivity and trait food cravings are predictive of a stronger attentional bias, especially in participants with obesity.

\section{Method}

This research was part of a larger study on the heritability of obesity, which was conducted as collaboration between the Academic Medical Center (Amsterdam, The Netherlands) and Maastricht University (Maastricht, The Netherlands). Participants were recruited from and tested either in the Amsterdam or the Maastricht area. The study procedures were approved by the Medical Ethics Committee of the Academic Medical Center and the Psychology Ethics Committee of Maastricht University.

\section{Participants}

Participants $(N=391)$ were recruited through advertisements in newspapers, supermarkets, hospitals, general practitioners, and obesity clinics. The advertisements called for Caucasian people, which was a requirement for the heritability aspect of the study, aged between 18 and 45 years, either healthy weight (body mass index [BMI] of 18 to 25 ) or obese (BMI $>30$ ), who were willing to participate in a study on the heritability of obesity. People with major neurological or psychiatric disorders; use of psychotropic medication; diseases affecting stomach, intestines, liver, kidneys or thyroid that could lead to an altered metabolism; and those who were pregnant or breastfeeding were excluded from participation. In addition, people who reported food deprivation were excluded. Participants with obesity and those of healthy weight were matched on a group level on age and gender. One participant was excluded because he reported not having had a proper meal in 2 weeks, and another participant for not following experimenter instructions. Twenty-five additional participants were excluded because their BMI was either below $18(n=2)$ or between 25 and $30(n=23)$. Finally, 45 healthy-weight participants did not match the obese group on age level. As age is a crucial factor, these participants were excluded. This left a sample of 319 participants: 134 healthy-weight (99 female, 35 male) individuals, and 185 individuals with obesity (131 female, 54 male). Participants received a compensation of $€ 25$ and reimbursement for traveling expenses.

\section{Measurements}

Visual search task. The visual search task (based on Smeets et al., 2009; Smeets, Roefs, van Furth, \& Jansen, 2008) is designed to measure attentional bias for food, and allows distinguishing between speeded detection of food and increased distraction by food. Diverging from the original task, which used only chocolate and candy pictures, in the current task, a distinction was made between high- and low-energy content to investigate whether attentional bias for food would be present for food in general, or for high-caloric food specifically. Items that were used were typical high-caloric (e.g., ice cream, crisps, burgers, French fries, pizza) and low-caloric (e.g., apples, crackers, carrots, grapes, broccoli) foods. In addition, the original task used bags and couches as neutral stimuli, whereas bags and balls were used in the current task. Participants were presented with a screen showing a $5 \times 4$ matrix of pictures from two of three different categories: neutral items, high-caloric foods, and low-caloric foods. The pictures were either all of the same category (odd-one-out absent) or one of them was from one of the other categories (odd-one-out present). The task for the participant was to decide as quickly and accurately as possible whether all pictures belonged to the same category, by pushing either a left ("all pictures belong to the same category") or right ("one picture belongs to a different category") button. Two different versions of the task were used in the study, counterbalanced across participants. In the first version, high-caloric food, 
low-caloric food, or a picture from Neutral Category I (e.g., balls) was presented among pictures of Neutral Category II (e.g., bags) for measuring detection, whereas a picture from Neutral Category II was presented among high-caloric food pictures, low-caloric food pictures, or pictures from Neutral Category I to measure distraction. In the second version, Neutral Category I was replaced by Neutral Category II, and vice versa. Before starting the task, participants performed 12 practice trials. The actual visual search task consisted of 154 trials (114 odd-one-out present and 40 odd-one-out absent), with a short break after 80 trials. During a trial, a short (100-ms) beep was presented, followed by a $500-\mathrm{ms}$ fixation point. This was succeeded by the picture matrix, which remained on the screen until the participant responded or $20 \mathrm{~s} \mathrm{had}$ passed. In case of a wrong, too-slow, or too-fast response, participants received feedback on the screen. A clear screen was presented for 1,500 ms before the next trial started. Pictures were randomly allocated to their positions in the matrix, with the restriction that they were never placed immediately below or above the fixation point.

Scores for detection speed were calculated by subtracting response latencies on trials with a neutral picture from Neutral Category I (e.g., a ball) among neutral pictures from Neutral Category II (e.g., bags) from trials with a food picture among neutral pictures from Neutral Category II (e.g., bags). Negative scores indicate faster detection of food items than of neutral items, whereas positive scores indicate the reverse (i.e., faster detection of neutral than of food items). Distraction was calculated by subtracting trials with one neutral picture from Neutral Category II (e.g., a bag) among neutral pictures from Neutral Category I (e.g., balls) from trials with one neutral picture from Neutral Category II (e.g., a ball) among food pictures. Positive scores are indicative of relatively more distraction by food than by neutral items, whereas negative scores indicate the reverse (i.e., more distraction by neutral than food items). Ultimately, each participant had a score for detection of high-caloric food, detection of low-caloric food, distraction by high-caloric food, and distraction by low-caloric food.

Stop signal task. The stop signal task is a measure of impulsivity, based on the premise that impulsivity has to do with the inability to inhibit responses (Logan, Schachar, \& Tannock, 1997). Participants perform a reaction time (RT) task (go-task) in which they are required to respond to a stimulus as quickly as possible. Within a trial, a fixation cross $(500 \mathrm{~ms})$ is followed by either an arrow on the right of the computer screen pointing to the right, or an arrow on the left side pointing to the left. Correct responses are pressing a button on the right or left, respectively. However, in $25 \%$ of the trials, participants are presented with an auditory stop signal (i.e., a beep administered through headphones) immediately after the stimulus, indicating that they have to inhibit their response. The time between the stimulus and stop signal (stop delay) varies in steps of $50 \mathrm{~ms}$ depending on how well the participant is capable of inhibiting his response, ultimately resulting in an accuracy of around $50 \%$ for everyone. By subtracting the mean stop delay from the mean RT on go-trials, the stop signal RT (SSRT) is calculated. A higher SSRT refers to less inhibitory control and higher impulsivity. In the current study, participants first performed 20 practice trials. These were followed by the actual task, consisting of four blocks containing 128 trials each. Participants could take short breaks in between blocks.
Delay discounting. Delay discounting is a measure of impulsivity based on the premise that impulsivity has to do with an increased sensitivity for immediate reward. Participants are presented with choices between hypothetical monetary rewards, of which one is a smaller immediate reward, and the other is a delayed larger reward. The time delay was either 2 weeks, 1 month, 6 months, 1 year, 3 years, 5 years, or 10 years (presented in random order). The point at which someone has no preference for either the immediate smaller reward or the delayed larger reward at a specific time delay is the indifference point for that time delay. In the particular task used in this study, the immediate reward was successively approaching the indifference point depending on the person's choices and varied in value from $€ 12$ to $€ 988$. The delayed reward was fixed at $€ 1000$. The subject was presented eight trials per time delay. Area under the curve (AUC) was calculated for all participants (Myerson, Green, \& Warusawitharana, 2001). AUCs were standardized to values between 0 and 1, with smaller AUCs reflecting steeper discounting and thus higher levels of impulsivity.

Barratt Impulsiveness Scale-Version 11 (BIS-11). The BIS-11 (Patton, Stanford, \& Barratt, 1995) is a 30-item self-report questionnaire, designed to measure trait impulsivity. Items have to be answered on a 4-point scale, with higher total scores reflecting higher levels of trait impulsivity. The BIS-11 has high internal consistency, test-retest reliability, and convergent validity (Patton et al., 1995; Stanford et al., 2009). The total BIS-11 score was used in the analyses. In the current study, Cronbach's alpha for the BIS-11 was .78.

General Food Craving Questionnaire-Trait (GFCQ-T). The GFCQ-T is a self-report questionnaire focusing on a general trait for food craving, and is a modification of the original version of the Trait Food Craving Questionnaire (TFCQ; Cepeda-Benito, Gleaves, Williams, \& Erath, 2000), translated and modified by Nijs, Franken, and Muris (2007), which measures craving for specific types of food. The GFCQ-T consists of 21 items to be scored on a 6-point Likert scale, ranging from never or not applicable to always. The questionnaire is reliable (as indicated by test-retest reliability and internal consistency) and valid, with good discriminant validity and construct validity (Nijs et al., 2007). The total GFCQ-T score was used in the analyses. Cronbach's alpha in the current study was .95 .

External eating and dietary restraint. External eating and dietary restraint were measured by the External Eating and Dietary Restraint subscales of the Dutch Eating Behavior Questionnaire (DEBQ; van Strien, 2005; van Strien, Frijters, Bergers, \& Defares, 1986a). Both subscales consist of 10 items regarding eating in response to food cues in the environment (external eating) and restricting food intake (dietary restraint). Answers are given on a 5-point Likert scale ranging from never to very often. Final scores range from 1 to 5 , with higher scores pointing to a higher degree of external eating or dietary behavior. The scales have high internal consistency and factorial validity (van Strien, et al., 1986a), and the Dietary Restraint subscale has moderate to good predictive validity (van Strien, Frijters, Van Staveren, Defares, \& Deurenberg, 1986b). However, a lack of discriminative and predictive validity for the External Eating subscale has been reported (Jansen et al., 2011). Cronbach's alphas for the external eating and dietary restraint subscales in the current study were .84 and .89 , respectively. 
Binge episodes. The Eating Disorder Examination (EDE; Cooper \& Fairburn, 1987) was used to assess the presence of binge episodes. The EDE is a semistructured interview designed to measure eating psychopathology. For the present study, only questions on objective episodes of overeating were included. Participants were considered to have binge episodes when those occurred at least once in the past 4 weeks. The EDE has good discriminant validity (Cooper, Cooper, \& Fairburn, 1989) as well as moderate convergent validity (Rosen, Vara, Wendt, \& Leitenberg, 1990).

Demographic information. Demographic information was collected through questionnaires. Participants were asked about their age, gender, daytime activities (answering options: student, employed, unemployed, housewife/houseman, other), living situation (answering options: alone, together with partner, together with partner and children, alone with children, alone with roommates, with parents/caregivers/foster parents), highest level of completed education (answering options: no education, primary education, and all different levels of the Dutch educational system in secondary and further education), personal income and family income (answering options for both questions in Euros: less than 1,000 [i.e., US $\$ 1,350$ ], 1,000-1,500, 1,500-2,000, 2,000-2,500, $2,500-3,000$, more than 3,000).

Physical measurements. To calculate BMI, participants' height and weight were measured using a stadiometer (brand: Seca) and a digital weighing scale (brands: Seca and MyWeigh) while they were wearing street clothes and no shoes. Experimenters were trained in the use of the stadiometer and weighing scale, and all had prior experience in taking these measures. Participants were asked to remove heavy clothing, such as jackets or thick vests. Participants whose hairstyle impeded height measurement were asked to untie their hair. Measurements were done once, and BMI was calculated using the following formula: weight $(\mathrm{kg}) /$ (height $[\mathrm{m}]^{2}$ ).

\section{Procedure}

Participants were individually invited to the lab and were instructed to eat something small (e.g., an apple or sandwich) $2 \mathrm{hr}$ before the start of the experiment to standardize hunger levels. Upon arrival, they received an explanation about the study and signed an informed consent form. They were then asked to take place behind a computer to execute the delay discounting task, stop signal task, and the visual search task. These computer tasks lasted for approximately $40 \mathrm{~min}$ in total. Instructions for the tasks were given by the experimenter and on the computer screen. At the end of the study, participants were interviewed about binge episodes, and filled out a battery of questionnaires, including demographic questions, the GFCQ-T, BIS-11, and DEBQ. Finally, height and weight were measured and the monetary compensation was given.

\section{Statistical Analysis}

Outlying data (i.e., $z$ score $>3.29$ ) on the stop signal task $(n=$ 2) and visual search task (high-caloric detection, $n=3$; lowcaloric detection, $n=1$; high-caloric distraction, $n=1$; lowcaloric distraction, $n=1$ ) were recoded into scores one unit (i.e., $1 \mathrm{~ms}$ ) larger than the largest nonoutlying score (Tabachnick, Fidell, \& Osterlind, 2001). With regard to the visual search task, only odd-one-out present trials were included in the analyses. Trials with errors $(13.20 \%)$ or slow responding $(M+3 S D)$ to correct trials were discarded $(0.27 \%$ of trials), as were trials slower than $20,000 \mathrm{~ms}$ (did not occur in odd-one-out present trials) or faster than $200 \mathrm{~ms}$ (.013\% of trials). Because of technical problems, stop signal task, visual search task, and delay discounting data were missing for 34 (16 with obesity), eight (two with obesity), and two (one with obesity) participants, respectively. One-way ANOVAs and Pearson chi-square tests were conducted to check for any preexisting differences between the obese and healthy-weight groups. To test the hypothesis, moderated regression analyses with simple slope testing and spotlight analyses at one standard deviation above or below the mean were carried out. The four components of the visual search task were the dependent variables and weight status, and either the GFCQ-T, BIS-11, delay discounting, or SSRT score was the independent variable. Thus, for each measure of impulsivity or craving, four moderated regressions were carried out: one for speeded detection of high-caloric food, one for speeded detection of low-caloric food, one for increased distraction by high-caloric food, and one for increased distraction by low-caloric food. In all analyses, age, gender, test location, DEBQ Dietary Restraint scores, DEBQ External Eating scores, presence of binge episodes, daytime activities, living situation, education level, and family income were entered as covariates in the first block. Nonsignificant variables were omitted from the model. In the second block, group (healthy-weight vs. obese) and BIS-11 score, GFCQ-T score, delay discounting (AUC), or SSRT were added. In the third and final block, the interaction between the two variables of the second block was entered. Variables were centered prior to entering them in the regression model. As indicated by Variance Inflation Factors (always close to 1) and Tolerance (never below 0.2 ), there were no multicollinearity problems in any of the conducted regressions. In addition, the DurbinWatson statistic had a value close to 2 in all analysis, indicating that the assumption of independence of errors was met. $P$ values below 0.05 were considered significant.

\section{Results}

\section{Sample Characteristics}

Table 1 shows the results of the one-way ANOVA testing for differences between the obese and healthy-weight groups on age, BMI, GFCQ-T, BIS-11, and DEBQ scores and the performance on the stop signal task, visual search task, and delay discounting task. Significant group differences emerged for age, BMI, GFCQ-T, BIS-11, DEBQ External Eating and DEBQ Dietary Restraint, with obese participants scoring higher on all these variables. Levene's test showed no homogeneity of variance for BMI, $F(1,317)=97.73, p<.001$, GFCQ-T, $F(1$, $317)=15.22, p<.001$, DEBQ External Eating, $F(1,317)=$ $5.27, p=.022$, DEBQ Dietary Restraint, $F(1,317)=12.30$, $p=.001$, and speeded detection of high-caloric food in the visual search task, $F(1,309)=5.33, p=.022$. Welch $F$ was used for these variables. A Pearson's chi-square test was performed on binge episodes, showing binges to be significantly more common in participants with obesity (46 out of 139 participants reported at least one binge episode in the past 4 weeks) than in healthy-weight participants (binge episodes reported by seven out of 127 participants), $\chi^{2}(1)=21.40, p<$ 
Table 1

Means and Standard Deviations of Participant Characteristics Per Group

\begin{tabular}{|c|c|c|c|c|c|c|c|}
\hline & \multicolumn{2}{|c|}{$\begin{array}{l}\text { Participants with } \\
\text { healthy weight } \\
(n=134)\end{array}$} & \multicolumn{2}{|c|}{$\begin{array}{l}\text { Participants with } \\
\text { obesity }(n=185)\end{array}$} & \multirow[b]{2}{*}{$F$} & \multirow[b]{2}{*}{$p$} & \multirow[b]{2}{*}{ Cohen's $d$} \\
\hline & $M$ & $S D$ & $M$ & $S D$ & & & \\
\hline Age & 33.04 & 8.15 & 35.19 & 7.59 & 5.90 & .02 & .27 \\
\hline BMI & 22.35 & 1.63 & 38.18 & 6.17 & 1110.72 & .00 & 3.51 \\
\hline GFCQ-T & 46.46 & 14.75 & 65.09 & 20.21 & 90.55 & .00 & 1.05 \\
\hline BIS-11 & 59.96 & 9.12 & 63.29 & 9.08 & 10.46 & .00 & .37 \\
\hline DEBQ-EX & 2.79 & 0.51 & 3.13 & 0.62 & 28.52 & .00 & .60 \\
\hline DEBQ-DR & 2.44 & 0.84 & 2.90 & 0.68 & 27.20 & .00 & .60 \\
\hline Delay discounting ${ }^{\mathrm{a}}$ & 0.50 & 0.23 & 0.46 & 0.25 & 2.26 & .13 & - \\
\hline SSRT & 179.76 & 45.74 & 176.36 & 43.07 & 0.41 & .53 & - \\
\hline VS he ds & -301.86 & 333.78 & -355.90 & 410.49 & 1.63 & .20 & - \\
\hline VS lc ds & -362.43 & 318.38 & -344.22 & 376.31 & 0.20 & .66 & - \\
\hline VS he di & 133.36 & 383.26 & 174.02 & 351.78 & 0.94 & .33 & - \\
\hline VS lc di & 167.56 & 447.70 & 204.75 & 406.39 & 0.58 & .45 & - \\
\hline
\end{tabular}

Note. $\quad$ BMI $=$ body mass index; GFCQ-T $=$ General Food Craving Questionnaire - Trait; BIS-11 = Barratt Impulsiveness Scale - 11; DEBQ = Dutch Eating Behavior Questionnaire; DEBQ-EX = External Eating subscale of the DEBQ; DEBQ-DR = Dietary Restraint subscale of the DEBQ; SSRT = Stop Signal Reaction Time; VS = Visual Search task; hc $=$ high-caloric food items; $1 \mathrm{c}=$ low-caloric food items; $\mathrm{ds}=$ detection speed (lower scores indicate faster detection of food); $\mathrm{di}=$ distraction (higher scores indicate more distraction by food).

${ }^{\text {a }}$ Values presented are areas under the curve.

.001. Additional Pearson chi-square tests on demographic variables (see Table 2) showed differences between the group with obesity and the group with normal weight on daytime activities, $\chi^{2}(4)=25.77, p<.001$, living situation, $\chi^{2}(5)=31.30, p<$ .001 , highest level of education $\chi^{2}(8)=63.56, p<.001$, and family income, $\chi^{2}(5)=17.17, p=.004$, but not personal income, $\chi^{2}(5)=5.47, p=.36$.

Hypothesis: Higher levels of impulsivity and trait food cravings are predictive of a stronger attention bias, especially in participants with obesity.

\section{Impulsivity: BIS-11}

Detection of high-caloric food. None of the covariates were significant, and they were therefore not retained in the model. The analysis showed a significant interaction between weight group and BIS-11 score, $\beta=-.18, t(310)=2.05, p=.041$, $f^{2}=.013$, indicating that participants with obesity and with a healthy weight differed in their detection speed of high-caloric food, depending on their degree of impulsivity. More specifically, within the high-impulsive participants, the participants with obesity were significantly faster at detecting high-caloric

Table 2

Cell Count Corresponding to Pearson Chi-Square Tests on Demographic Variables

\begin{tabular}{|c|c|c|c|c|c|c|c|c|}
\hline $\begin{array}{l}\text { Daytime activities } \\
\text { Healthy-weight } \\
\text { Obese }\end{array}$ & $\begin{array}{l}\text { Student } \\
32 \\
16\end{array}$ & $\begin{array}{c}\text { Employed } \\
77 \\
132\end{array}$ & $\begin{array}{c}\text { Unemployed } \\
18 \\
11\end{array}$ & $\begin{array}{c}\text { Housewife/man } \\
5 \\
23\end{array}$ & $\begin{array}{c}\text { Other } \\
2 \\
3\end{array}$ & & & \\
\hline $\begin{array}{l}\text { Living situation } \\
\text { Healthy-weight } \\
\text { Obese }\end{array}$ & $\begin{array}{l}\text { Alone } \\
38 \\
40\end{array}$ & $\begin{array}{c}\text { With partner } \\
37 \\
36\end{array}$ & $\begin{array}{l}\text { With partner and children } \\
\qquad \begin{array}{c}22 \\
74\end{array}\end{array}$ & $\begin{array}{c}\text { Alone with children } \\
9 \\
14\end{array}$ & $\begin{array}{c}\text { Alone with roommates } \\
21 \\
7\end{array}$ & $\begin{array}{c}\text { With parents } \\
7 \\
14\end{array}$ & & \\
\hline $\begin{array}{l}\text { Educational level } \\
\text { Healthy-weight } \\
\text { Obese }\end{array}$ & $\begin{array}{c}\text { None } \\
1 \\
0\end{array}$ & $\begin{array}{c}\text { Primary } \\
3 \\
1\end{array}$ & $\begin{array}{c}\text { VMBO/MAVO } \\
7 \\
32\end{array}$ & $\begin{array}{l}\text { HAVO } \\
9 \\
14\end{array}$ & $\begin{array}{l}\text { VWO } \\
14 \\
14\end{array}$ & $\begin{array}{l}\text { MBO } \\
16 \\
68\end{array}$ & $\begin{array}{l}\text { HBO } \\
39 \\
42\end{array}$ & $\begin{array}{l}\text { WO } \\
45 \\
14\end{array}$ \\
\hline $\begin{array}{l}\text { Personal income } \\
\text { Healthy-weight } \\
\text { Obese }\end{array}$ & $\begin{array}{l}<€ 1000 \\
53 \\
55\end{array}$ & $\begin{array}{c}€ 1000-1500 \\
28 \\
49\end{array}$ & $\begin{array}{c}€ 1500-2000 \\
26 \\
41\end{array}$ & $\begin{array}{c}€ 2000-2500 \\
19 \\
22\end{array}$ & $\begin{array}{c}€ 2500-3000 \\
5 \\
9\end{array}$ & $\begin{array}{c}>€ 3000 \\
3 \\
9\end{array}$ & & \\
\hline $\begin{array}{l}\text { Family income } \\
\text { Healthy-weight } \\
\text { Obese }\end{array}$ & $\begin{array}{c}<€ 1000 \\
28 \\
12\end{array}$ & $\begin{array}{c}€ 1000-1500 \\
18 \\
27\end{array}$ & $\begin{array}{c}€ 1500-2000 \\
19 \\
33\end{array}$ & $\begin{array}{c}€ 2000-2500 \\
16 \\
38\end{array}$ & $\begin{array}{c}€ 2500-3000 \\
21 \\
27\end{array}$ & $\begin{array}{c}>€ 3000 \\
32 \\
48\end{array}$ & & \\
\hline
\end{tabular}

Note VMBO/MAVO, HAVO, and VWO are forms of secondary education, with VMBO/MAVO being the lowest level and VWO the highest level. $\mathrm{MBO}, \mathrm{HBO}$, and $\mathrm{WO}$ are forms of further education, corresponding to the three types of secondary education. HBO corresponds to college in the United States, and WO corresponds to university in the United States. VMBO = Voorbereidend Middelbaar Beroepsonderwijs; MAVO = Middelbaar Algemeen Voortgezet Onderwijs; HAVO = Hoger Algemeen Voortgezet Onderwijs; VWO = Voorbereidend Wetenschappelijk Onderwijs; HBO = Hoger Beroepsonderwijs; WO = Wetenschappelijk Onderwijs. 
food than the healthy-weight participants, $\beta=-.19, t(310)=$ $2.32, p=.021$. There was no difference within the lowimpulsive participants, $\beta=.04, t(310)=.52, p=.60$. Within the participants with obesity and within the healthy-weight participants, there was no effect of impulsivity (obese: $\beta=-.10, t[310]=1.34, p=.18$; healthy-weight: $\beta=.14$, $t[310]=1.55, p=.122)$. Simple slopes and interactions with standardized regression coefficients for participants scoring high $(+1 S D)$ and low $(-1 S D)$ on impulsivity are plotted in Figure 1. Results of this regression analysis can be found in Table 3.

Detection of low-caloric food. Location was a borderline significant $(p=.056)$ covariate and was therefore retained in the model. There was no interaction between BIS-11 scores and weight group, $\beta=-.16, t(310)=1.77, p=.077$, indicating no role of trait impulsivity in the relationship between weight status and the detection speed of low-caloric food items.

Distraction by high- and low-caloric food. There was no significant interaction between weight status and BIS-11 score for distraction by either high-caloric, $\beta=.035, t(310)=.46, p=$ .647 , or low-caloric, $\beta=.092, t(310)=1.22, p=.224$, food. These findings indicate no effect of self-reported impulsivity and weight status on being distracted by food.

\section{Impulsivity-SSRT}

The Weight Status $\times$ SSRT interaction was nonsignificant for detection of high-caloric food, $\beta=-.037, t(283)=-.47, p=.639$, detection of low-caloric food, $\beta=.077, t(283)=.98, p=.329$, distraction by high-caloric food, $\beta=.008, t(283)=.10, p=.922$, or distraction by low-caloric food, $\beta=-.002, t(283)=-.024$, $p=.981$. In sum, there was no effect of weight status and SSRT on an attention bias for food.

\section{Impulsivity-Delay Discounting}

We found no significant interaction between weight status and delay discounting scores for detection of high-caloric food, $\beta=$ $.134, t(309)=1.44, p=.151$, detection of low-caloric food, $\beta=$ $.019, t(309)=.207, p=.836$, distraction by high-caloric food,

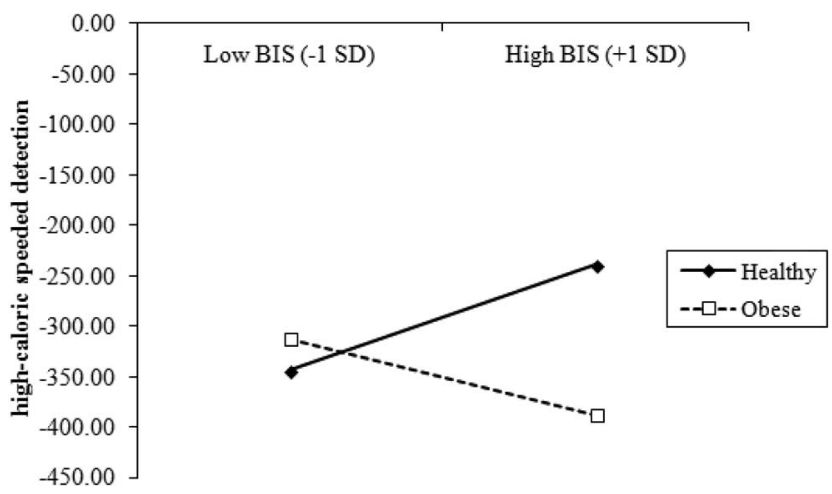

Figure 1. Detection speed of high-caloric food as a function of weight and Barratt Impulsiveness Scale - Version 11 (BIS-11) impulsivity scores (-1 SD and +1 SD from the mean BIS-11 score, respectively). Lower scores indicate faster detection of food stimuli.
Table 3

Results of Moderated Regression Analysis of Weight Group and BIS-11 Scores on Speeded Detection of High-Caloric Food

\begin{tabular}{|c|c|c|c|c|}
\hline \multirow[b]{3}{*}{ Steps and variables } & \multicolumn{4}{|c|}{ High-caloric speeded detection } \\
\hline & \multicolumn{2}{|c|}{ Step 1} & \multicolumn{2}{|c|}{ Step 2} \\
\hline & $B$ & $S E$ & $B$ & $S E$ \\
\hline Weight group & -53.90 & 44.59 & -58.25 & 44.41 \\
\hline BIS-11 & -0.04 & 2.37 & 5.66 & 3.65 \\
\hline Weight Group $\times$ BIS-11 & & & $-9.78^{*}$ & 4.78 \\
\hline$R^{2}$ & \multicolumn{2}{|c|}{005} & \multicolumn{2}{|c|}{.018} \\
\hline$\Delta R^{2}$ & \multicolumn{2}{|c|}{.005} & \multicolumn{2}{|c|}{$.013^{*}$} \\
\hline
\end{tabular}

Note. $B$ is the unstandardized regression coefficient.

$* p<.05$.

$\beta=.083, t(309)=.89, p=.373$, or distraction by low-caloric food, $\beta=.134, t(309)=1.44, p=.151$. Taken together, these results indicate no influence of reward sensitivity and weight status on attention bias for food.

\section{Trait Craving-GFCQ-T}

There were nonsignificant interactions between weight status and GFCQ-T scores for detection of high-caloric food, $\beta=.061$, $t(310)=.80, p=.426$, detection of low-caloric food, $\beta=.027$, $t(310)=.35, p=.729$, distraction by high-caloric food, $\beta=-.029, t(310)=-.38, p=.702$, and distraction by lowcaloric food, $\beta=-.004, t(310)=-.05, p=.963$. These results show that weight status and trait food craving do not influence attention bias for food.

\section{Discussion}

Results of the present study showed that trait impulsivity moderated the relationship between obesity and attention bias: Highimpulsive participants with obesity were significantly faster than high-impulsive healthy-weight participants in detecting a highcaloric food item among neutral items. All other analyses, including those using the other two measures of attentional bias (i.e., distraction by high- and low-caloric foods) and other measures of impulsivity (i.e., stop signal task, delay discounting task) or trait craving did not yield significant results.

These results point out that in our participants with obesity, an impulsive personality is associated with a speedy detection of high-caloric food, whereas this is not the case in healthy weights. High-calorie foods are more salient and more rewarding for people with obesity than for healthy weights (Stice, Spoor, Bohon, Veldhuizen, \& Small, 2008; Stoeckel et al., 2008), and therefore they might more easily draw the attention of impulsive people with obesity. In healthy-weight impulsive people, immediate pleasure might be derived from other sources than palatable food. A preference for high-caloric food seems to be less pronounced in the healthy-weight population (Ransley et al., 2003; Stoeckel et al., 2008), and an additional lack of impulsivity might lower such a preference even more.

Remarkably, we only found these effects with self-reported trait impulsivity and not when impulsivity was measured with behavioral tasks. Whereas trait impulsivity refers to a general impulsive 
personality, behavioral tasks measure only one specific state-like aspect of impulsivity, in this case, response inhibition or sensitivity to immediate reward. Apparently, these specific aspects of impulsivity do not influence attention for food, whereas being a generally impulsive person does. However, exactly why this would happen remains unclear. Perhaps the specificity of the behavioral tasks limits generalization to other behaviors (Reynolds et al., 2006). Furthermore, impulsivity questionnaires do not fully reflect the behavioral measures and can therefore not be assumed to measure the same. The results do add to a growing body of literature demonstrating no or weak correlations between different self-report and behavioral measures of impulsivity (Enticott, Ogloff, \& Bradshaw, 2006; Marsh, Dougherty, Mathias, Moeller, \& Hicks, 2002; Reynolds et al., 2006), thereby stressing the multidimensionality of the impulsivity construct. In line with our results, Hou et al. (2011) found a correlation between self-reported trait impulsivity and attentional bias for food cues. It thus seems that self-reported trait impulsivity is a more critical factor than response inhibition or reward sensitivity in understanding attention biases for food cues. These findings on food attentional bias differ from substance-related biases, however: A recent meta-analysis showed a significantly stronger relationship between behavioral measures of impulsivity and substance-related attentional bias than between self-reported trait measures and such an attentional bias (Coskunpinar \& Cyders, 2013). Without doubt, impulsivity is a complicated construct that can be conceptualized in many ways (Dawe \& Loxton, 2004). It remains a question for future research to see whether a different conceptualization would lead to different results. Likewise, measures of attentional bias vary across studies as well, using, for example, dot-probe versus visual-search tasks, food words versus food pictures, and some including eye-tracking measurements. It cannot be ruled out that alternative measures of attention bias would have yielded different results.

Another noteworthy finding related to the three types of impulsivity measures is that we did show higher impulsivity in participants with obesity compared with healthy-weight participants on self-reported trait impulsivity, but not on behavioral tasks. Our findings on self-report are in concordance with previous studies (Fassino et al., 2002; Mobbs et al., 2010; Rydén et al., 2003), whereas the findings on response inhibition (Hendrick, Luo, Zhang, \& Li, 2012; Nederkoorn et al., 2006) and delay discounting (Nederkoorn et al., 2006; Weller, Cook, Avsar, \& Cox, 2008; Yeomans, Leitch, \& Mobini, 2008) are mixed. Whether and how weight is related to effective response inhibition and reward sensitivity are questions that remain to be answered.

The absence of any findings on the influence of trait craving on attention bias is surprising, as studies including trait chocolate cravers have found both increased distraction by and speeded detection of chocolate cues (Kemps \& Tiggemann, 2009; Smeets et al., 2009). Future studies might test whether trait craving for a specific food in combination with an attention bias paradigm involving that particular food elicits stronger effects than general trait food craving with an attention task consisting of different types of tasty foods, as was the case in the present study.

Finally, we would like to note that trait impulsivity is linked to the dopaminergic system. More specifically, a recent imaging study showed that trait impulsivity is negatively associated with the expression of midbrain dopamine $\mathrm{D}_{2 / 3}$ autoreceptors and with amphetamine-induced release of endogenous striatal dopamine
(Buckholtz et al., 2010). In addition, we and others showed loss of striatal $\mathrm{D}_{2 / 3}$ receptors in obesity (de Weijer, et al., 2011; van de Giessen, Celik, Schweitzer, van den Brink, \& Booij, 2014; Wang et al., 2001), which are located predominantly postsynaptically. Taking into account these results, as well as the results of the present study, it would be interesting to evaluate, in future studies, whether impulsive patients with obesity, compared with nonimpulsive patients with obesity, show loss of expression of midbrain dopamine $\mathrm{D}_{2 / 3}$ autoreceptors as well as an increased striatal dopamine release, and whether this is also related to increased attentional bias for high-caloric food.

This study has some limitations. First, there was an overrepresentation of (former) students in the normal-weight group. Although the participants were matched on age and gender, differences between groups emerged on other demographic variables, namely, level of education, living situation, daytime activities, and family income. A second limitation of the present study concerns the absence of hunger and craving measures before administration of the visual search paradigm, as previous studies have indicated that these could be influential variables (see, e.g., Castellanos et al., 2009, and Werthmann et al., 2011). However, all participants were instructed to eat something small $2 \mathrm{hr}$ before the start of the experiment to standardize hunger levels. Third, because information on construct validity was not available for all used questionnaires, we cannot be certain whether the constructs used were adequately measured. However, all questionnaires are among the most well-known and commonly used in the field, ensuring the possibility of comparing our results with those of other studies.

Finally, it is important to note that only one of the measures yielded significant results, and that the effects obtained by this measure were quite small. It is therefore too early to draw firm conclusions about the role of impulsivity in attentional bias for food. However, if the results of the present study can be replicated, they could be of relevance for clinical practice, as they underline the role of self-reported impulsivity in the relationship between weight status and attentional bias for food cues. Of most clinical relevance is the finding that highimpulsive participants with obesity were faster at detecting high-caloric foods than their low-impulsive counterparts, suggesting that impulsivity should be taken into account as an additional factor in the treatment of obesity or overweight in clinical practice. In addition, attention retraining in which patients are trained to avoid or disengage attention from food cues could be useful to reduce the attention-grabbing powers of food in this particular group of high-impulsive people with obesity. Studies in groups of heavy drinkers (Schoenmakers, Wiers, Jones, Bruce, \& Jansen, 2007), abstinent alcohol-dependent patients (Schoenmakers et al., 2010; Wiers, Eberl, Rinck, Becker, \& Lindenmeyer, 2011), smokers (Attwood, O'Sullivan, Leonards, Mackintosh, \& Munafò, 2008), and concerning food intake (Werthmann et al., 2014) have yielded promising results in this regard.

In conclusion, trait impulsivity is associated with increased attentional bias for high-calorie food in people with obesity, but not in people with a healthy weight. This characteristic might make it more difficult for impulsive overweight people to live in a society with an overwhelming presence of high-caloric food. 


\section{References}

Attwood, A. S., O’Sullivan, H., Leonards, U., Mackintosh, B., \& Munafò, M. R. (2008). Attentional bias training and cue reactivity in cigarette smokers. Addiction, 103, 1875-1882. http://dx.doi.org/10.1111/j.13600443.2008.02335.x

Buckholtz, J. W., Treadway, M. T., Cowan, R. L., Woodward, N. D., Li, R., Ansari, M. S., . . . Zald, D. H. (2010). Dopaminergic network differences in human impulsivity. Science, 329, 532. http://dx.doi.org/ $10.1126 /$ science. 1185778

Castellanos, E. H., Charboneau, E., Dietrich, M. S., Park, S., Bradley, B. P., Mogg, K., \& Cowan, R. L. (2009). Obese adults have visual attention bias for food cue images: Evidence for altered reward system function. International Journal of Obesity, 33, 1063-1073. http://dx.doi .org/10.1038/ijo.2009.138

Cepeda-Benito, A., Gleaves, D. H., Williams, T. L., \& Erath, S. A. (2000). The development and validation of the State and Trait Food-Cravings Questionnaire. Behavior Therapy, 31, 151-173.

Cooper, Z., Cooper, P. J., \& Fairburn, C. G. (1989). The validity of the eating disorder examination and its subscales. The British Journal of Psychiatry, 154, 807-812. http://dx.doi.org/10.1192/bjp.154.6.807

Cooper, Z., \& Fairburn, C. (1987). The eating disorder examination: A semi-structured interview for the assessment of the specific psychopathology of eating disorders. International Journal of Eating Disorders, 6, 1-8. http://dx.doi.org/10.1002/1098-108X(198701)6:1<1::AIDEAT2260060102>3.0.CO;2-9

Coskunpinar, A., \& Cyders, M. A. (2013). Impulsivity and substancerelated attentional bias: A meta-analytic review. Drug and Alcohol Dependence, 133, 1-14. http://dx.doi.org/10.1016/j.drugalcdep.2013.05 .008

Dawe, S., \& Loxton, N. J. (2004). The role of impulsivity in the development of substance use and eating disorders. Neuroscience and Biobehavioral Reviews, 28, 343-351. http://dx.doi.org/10.1016/j.neubiorev .2004 .03 .007

de Weijer, B. A., van de Giessen, E., van Amelsvoort, T. A., Boot, E., Braak, B., Janssen, I. M., . . . Booij, J. (2011). Lower striatal dopamine D2/3 receptor availability in obese compared with non-obese subjects. EJNMMI Research, 1, 1-5.

de Wit, H. (2009). Impulsivity as a determinant and consequence of drug use: A review of underlying processes. Addiction Biology, 14, 22-31. http://dx.doi.org/10.1111/j.1369-1600.2008.00129.x

Enticott, P. G., Ogloff, J. R., \& Bradshaw, J. L. (2006). Associations between laboratory measures of executive inhibitory control and selfreported impulsivity. Personality and Individual Differences, 41, 285294. http://dx.doi.org/10.1016/j.paid.2006.01.011

Fassino, S., Leombruni, P., Pierò, A., Daga, G. A., Amianto, F., Rovera, G., \& Rovera, G. G. (2002). Temperament and character in obese women with and without binge eating disorder. Comprehensive Psychiatry, 43, 431-437. http://dx.doi.org/10.1053/comp.2002.35906

Field, M., \& Cox, W. M. (2008). Attentional bias in addictive behaviors: A review of its development, causes, and consequences. Drug and Alcohol Dependence, 97, 1-20. http://dx.doi.org/10.1016/j.drugalcdep .2008.03.030

Galanti, K., Gluck, M. E., \& Geliebter, A. (2007). Test meal intake in obese binge eaters in relation to impulsivity and compulsivity. International Journal of Eating Disorders, 40, 727-732. http://dx.doi.org/ 10.1002/eat.20441

Guerrieri, R., Nederkoorn, C., \& Jansen, A. (2007a). How impulsiveness and variety influence food intake in a sample of healthy women. Appetite, 48, 119-122. http://dx.doi.org/10.1016/j.appet.2006.06.004

Guerrieri, R., Nederkoorn, C., \& Jansen, A. (2008). The effect of an impulsive personality on overeating and obesity: Current state of affairs. Psihologijske Teme, 17, 265-286.

Guerrieri, R., Nederkoorn, C., Schrooten, M., Martijn, C., \& Jansen, A. (2009). Inducing impulsivity leads high and low restrained eaters into overeating, whereas current dieters stick to their diet. Appetite, 53, 93-100. http://dx.doi.org/10.1016/j.appet.2009.05.013

Guerrieri, R., Nederkoorn, C., Stankiewicz, K., Alberts, H., Geschwind, N., Martijn, C., \& Jansen, A. (2007b). The influence of trait and induced state impulsivity on food intake in normal-weight healthy women. Appetite, 49, 66-73. http://dx.doi.org/10.1016/j.appet.2006.11.008

Hendrick, O. M., Luo, X., Zhang, S., \& Li, C. S. (2012). Saliency processing and obesity: A preliminary imaging study of the stop signal task. Obesity, 20, 1796-1802. http://dx.doi.org/10.1038/oby.2011.180

Hou, R., Mogg, K., Bradley, B. P., Moss-Morris, R., Peveler, R., \& Roefs, A. (2011). External eating, impulsivity and attentional bias to food cues. Appetite, 56, 424-427. http://dx.doi.org/10.1016/j.appet.2011.01.019

Jansen, A., Nederkoorn, C., Roefs, A., Bongers, P., Teugels, T., \& Havermans, R. (2011). The proof of the pudding is in the eating: Is the DEBQ-external eating scale a valid measure of external eating? International Journal of Eating Disorders, 44, 164-168.

Jansen, A., Nederkoorn, C., van Baak, L., Keirse, C., Guerrieri, R., \& Havermans, R. (2009). High-restrained eaters only overeat when they are also impulsive. Behaviour Research and Therapy, 47, 105-110. http://dx.doi.org/10.1016/j.brat.2008.10.016

Kemps, E., \& Tiggemann, M. (2009). Attentional bias for craving-related (chocolate) food cues. Experimental and Clinical Psychopharmacology, 17, 425-433. http://dx.doi.org/10.1037/a0017796

Logan, G. D., Schachar, R. J., \& Tannock, R. (1997). Impulsivity and inhibitory control. Psychological Science, 8, 60-64. http://dx.doi.org/ 10.1111/j.1467-9280.1997.tb00545.x

Marsh, D. M., Dougherty, D. M., Mathias, C. W., Moeller, F. G., \& Hicks, L. R. (2002). Comparisons of women with high and low trait impulsivity using behavioral models of response-disinhibition and reward-choice. Personality and Individual Differences, 33, 1291-1310. http://dx.doi .org/10.1016/S0191-8869(02)00014-4

Mobbs, O., Crépin, C., Thiéry, C., Golay, A., \& Van der Linden, M. (2010). Obesity and the four facets of impulsivity. Patient Education and Counseling, 79, 372-377. http://dx.doi.org/10.1016/j.pec.2010.03 .003

Myerson, J., Green, L., \& Warusawitharana, M. (2001). Area under the curve as a measure of discounting. Journal of the Experimental Analysis of Behavior, 76, 235-243. http://dx.doi.org/10.1901/jeab.2001.76-235

Nederkoorn, C., Smulders, F. T., Havermans, R. C., Roefs, A., \& Jansen, A. (2006). Impulsivity in obese women. Appetite, 47, 253-256. http:// dx.doi.org/10.1016/j.appet.2006.05.008

Nijs, I. M. T., Franken, I. H. A., \& Muris, P. (2007). The modified Trait and State Food-Cravings Questionnaires: Development and validation of a general index of food craving. Appetite, 49, 38-46. http://dx.doi.org/ 10.1016/j.appet.2006.11.001

Nijs, I. M. T., Muris, P., Euser, A. S., \& Franken, I. H. A. (2010) Differences in attention to food and food intake between overweight/ obese and normal-weight females under conditions of hunger and satiety. Appetite, 54, 243-254. http://dx.doi.org/10.1016/j.appet.2009.11 004

Nummenmaa, L., Hietanen, J. K., Calvo, M. G., \& Hyönä, J. (2011). Food catches the eye but not for everyone: A BMI-contingent attentional bias in rapid detection of nutriments. PLOS ONE, 6, e19215. http://dx.doi .org/10.1371/journal.pone.0019215

Papachristou, H., Nederkoorn, C., Havermans, R., van der Horst, M., \& Jansen, A. (2012). Can't stop the craving: The effect of impulsivity on cue-elicited craving for alcohol in heavy and light social drinkers. Psychopharmacology, 219, 511-518. http://dx.doi.org/10.1007/s00213011-2240-5

Patton, J. H., Stanford, M. S., \& Barratt, E. S. (1995). Factor structure of the Barratt impulsiveness scale. Journal of Clinical Psychology, 51, 768-774. http://dx.doi.org/10.1002/1097-4679(199511)51:6<768:: AID-JCLP2270510607>3.0.CO;2-1 
Ransley, J. K., Donnelly, J. K., Botham, H., Khara, T. N., Greenwood, D. C., \& Cade, J. E. (2003). Use of supermarket receipts to estimate energy and fat content of food purchased by lean and overweight families. Appetite, 41, 141-148. http://dx.doi.org/10.1016/S01956663(03)00051-5

Reynolds, B., Ortengren, A., Richards, J. B., \& de Wit, H. (2006). Dimensions of impulsive behavior: Personality and behavioral measures. Personality and Individual Differences, 40, 305-315. http://dx.doi.org/ 10.1016/j.paid.2005.03.024

Rosen, J. C., Vara, L., Wendt, S., \& Leitenberg, H. (1990). Validity studies of the eating disorder examination. International Journal of Eating Disorders, 9, 519-528. http://dx.doi.org/10.1002/1098-108X(199009)9: 5<519::AID-EAT2260090507>3.0.CO;2-K

Rydén, A., Sullivan, M., Torgerson, J. S., Karlsson, J., Lindroos, A. K., \& Taft, C. (2003). Severe obesity and personality: A comparative controlled study of personality traits. International Journal of Obesity, 27, 1534-1540. http://dx.doi.org/10.1038/sj.ijo.0802460

Schoenmakers, T., Wiers, R. W., Jones, B. T., Bruce, G., \& Jansen, A. T. (2007). Attentional re-training decreases attentional bias in heavy drinkers without generalization. Addiction, 102, 399-405. http://dx.doi.org/ 10.1111/j.1360-0443.2006.01718.x

Schoenmakers, T. M., de Bruin, M., Lux, I. F., Goertz, A. G., Van Kerkhof, D. H., \& Wiers, R. W. (2010). Clinical effectiveness of attentional bias modification training in abstinent alcoholic patients. Drug and Alcohol Dependence, 109, 30-36. http://dx.doi.org/10.1016/j.drugalcdep.2009 .11 .022

Smeets, E., Roefs, A., \& Jansen, A. (2009). Experimentally induced chocolate craving leads to an attentional bias in increased distraction but not in speeded detection. Appetite, 53, 370-375. http://dx.doi.org/ 10.1016/j.appet.2009.07.020

Smeets, E., Roefs, A., van Furth, E., \& Jansen, A. (2008). Attentional bias for body and food in eating disorders: Increased distraction, speeded detection, or both? Behaviour Research and Therapy, 46, 229-238. http://dx.doi.org/10.1016/j.brat.2007.12.003

Stanford, M. S., Mathias, C. W., Dougherty, D. M., Lake, S. L., Anderson, N. E., \& Patton, J. H. (2009). Fifty years of the Barratt Impulsiveness Scale: An update and review. Personality and Individual Differences, 47, 385-395. http://dx.doi.org/10.1016/j.paid.2009.04.008

Stice, E., Spoor, S., Bohon, C., Veldhuizen, M. G., \& Small, D. M. (2008). Relation of reward from food intake and anticipated food intake to obesity: A functional magnetic resonance imaging study. Journal of Abnormal Psychology, 117, 924-935. http://dx.doi.org/10.1037/ a0013600

Stoeckel, L. E., Weller, R. E., Cook, E. W., III, Twieg, D. B., Knowlton, R. C., \& Cox, J. E. (2008). Widespread reward-system activation in obese women in response to pictures of high-calorie foods. NeuroImage, 41, 636-647. http://dx.doi.org/10.1016/j.neuroimage.2008.02.031

Tabachnick, B. G., Fidell, L. S., \& Osterlind, S. J. (2001). Using multivariate statistics. Boston, MA: Allyn and Bacon. van de Giessen, E., Celik, F., Schweitzer, D. H., van den Brink, W., \& Booij, J. (2014). Dopamine D2/3 receptor availability and amphetamineinduced dopamine release in obesity. Journal of Psychopharmacology (Oxford, England), 28, 866-873. http://dx.doi.org/10.1177/ 0269881114531664

van Strien, T. (2005). Nederlandse Vragenlijst voor Eetgedrag 2005. Handleiding en Verantwoording [Manual of the Dutch Eating Behavior Questionnaire 2005]. Amsterdam, Netherlands: Boom test uitgevers.

van Strien, T., Frijters, J. E., Bergers, G. P., \& Defares, P. B. (1986a). The Dutch Eating Behavior Questionnaire (DEBQ) for assessment of restrained, emotional, and external eating behavior. International Journal of Eating Disorders, 5, 295-315. http://dx.doi.org/10.1002/1098108X(198602)5:2<295::AID-EAT2260050209>3.0.CO;2-T

van Strien, T., Frijters, J. E. R., Van Staveren, W. A., Defares, P. B., \& Deurenberg, P. (1986b). The predictive validity of the Dutch restrained eating scale. International Journal of Eating Disorders, 5, 747-755. http://dx.doi.org/10.1002/1098-108X(198605)5:4<747::AIDEAT2260050413>3.0.CO;2-6

Wang, G.-J., Volkow, N. D., Logan, J., Pappas, N. R., Wong, C. T., Zhu, W., . . Fowler, J. S. (2001). Brain dopamine and obesity. Lancet, 357 354-357. http://dx.doi.org/10.1016/S0140-6736(00)03643-6

Weller, R. E., Cook, E. W., III, Avsar, K. B., \& Cox, J. E. (2008). Obese women show greater delay discounting than healthy-weight women Appetite, 51, 563-569. http://dx.doi.org/10.1016/j.appet.2008.04.010

Werthmann, J., Field, M., Roefs, A., Nederkoorn, C., \& Jansen, A. (2014). Attention bias for chocolate increases chocolate consumption-An attention bias modification study. Journal of Behavior Therapy and Experimental Psychiatry, 45, 136-143. http://dx.doi.org/10.1016/j.jbtep 2013.09.009

Werthmann, J., Roefs, A., Nederkoorn, C., Mogg, K., Bradley, B. P., \& Jansen, A. (2011). Can(not) take my eyes off it: Attention bias for food in overweight participants. Health Psychology, 30, 561-569. http://dx .doi.org/10.1037/a0024291

Whiteside, S. P., \& Lynam, D. R. (2001). The five factor model and impulsivity: Using a structural model of personality to understand impulsivity. Personality and Individual Differences, 30, 669-689. http:// dx.doi.org/10.1016/S0191-8869(00)00064-7

Wiers, R. W., Eberl, C., Rinck, M., Becker, E. S., \& Lindenmeyer, J. (2011). Retraining automatic action tendencies changes alcoholic patients' approach bias for alcohol and improves treatment outcome. Psychological Science, 22, 490-497. http://dx.doi.org/10.1177/ 0956797611400615

Yeomans, M. R., Leitch, M., \& Mobini, S. (2008). Impulsivity is associated with the disinhibition but not restraint factor from the Three Factor Eating Questionnaire. Appetite, 50, 469-476. http://dx.doi.org/10.1016/j.appet .2007 .10 .002

Received February 12, 2014

Revision received August 29, 2014 Accepted August 30, 2014 